\title{
喉頭筋電図にて甲状披裂筋麻痺の確定診断が 得られた症例の臨床的検討
}

\author{
宮本真宮田恵里友田幸一
}

要 約：反回神経は，後輪状披裂筋，披裂筋，外側輪状披裂筋，甲状披裂筋の順番に分枝を 出しており，個々の分枝は非常に局所の障害で影響を受ける可能性がある。理論的には甲状披 裂筋麻痺は存在し, この麻痺は部分的喉頭麻痺と呼ばれている。しかし甲状披裂筋麻痺はまれ とされている.

今回われわれは，甲状披裂筋麻痺の 5 症例を経験したので，若干の文献的考察を加え報告す る。症例は男性 3 名, 女性 2 名で, うち 3 名は全身麻酔下の手術後に認めた。喉頭所見は全員, 声帯の内転と外転運動は正常で, 麻痺側声帯膜様部の弓状弛緩を認めた。甲状披裂筋麻痺の診 断には，喉頭内視鏡のみでは不十分であり，喉頭筋電図が必要と考えられた。音声所見では， 声門閉鎖不全による気息性嗄声と，甲状披裂筋と輪状披裂筋の拮抗作用が障害された声区の調 節障害が特徵的であった。

索引用語 : 甲状披裂筋麻痺, 部分的喉頭麻痺, 声帯の弓状弛緩, 喉頭筋電困, 声区の調節障 宫

\section{Analysis of Cases Diagnosed as Thyroarytenoid Muscle Paralysis Using Laryngeal Electromyogram}

Makoto Miyamoto, Eri Miyata and Koichi Tomoda

\begin{abstract}
The recurrent laryngeal nerve sequentially branches into the posterior cricoarytenoid muscle, arytenoid muscle, lateral cricoarytenoid muscle and thyroarytenoid muscle, and each individual branch seems to be readily susceptible to localized penetrating injury. Thyroarytenoid muscle paralysis exists in theory and is referred to as partial vocal cord paralysis. Such cases are extremely rare, however.

Here we report five cases of thyroarytenoid muscle paralysis. Three cases were male and two female, and three among the five patients experienced partial vocal cord paralysis after surgery under general anesthesia. The laryngeal findings of all patients showed normal abductor and adductor actions on the vocal cords and bowing of the vocal cord on the paralyzed side. We believed that diagnosis of thyroidarytenoid muscle paralysis requires not only confirmation by laryngeal endoscopy but also by laryngeal electromyogram. Breathy hoarseness caused by a glottal gap and accommodation disorder of the voice register involving antagonism between the cricoarytenoid and thyroarytenoid muscles seemed
\end{abstract}

関西医科大学枚方病院耳鼻咽喉科・頭頸部外科：=573-1191 大阪府枚方市新町 2-3-1

Department of Otorhinolaryngology-Head \& Neck Surgery, Kansai Medical University Hirakata Hospital: 2-3-1, Shinmachi, Hiralata, Osaka 573-1191, Japan

2014 年 2 月 2 日受稿 2014 年 5 月 26 日受理 
characteristic of these cases.

Key words: thyroarytenoid muscle paralysis, partial vocal cord paralysis, bowing of the vocal cord on the paralyzed side, laryngeal electromyogram, accommodation disorder of the voice register

\section{はじめに}

甲状披裂筋麻疩とは，部分的な喉頭麻瘏，つまり反 回神経支配下の甲状披裂筋単独の麻痖である。しかし 甲状披裂筋麻痺はまれで，その診断には喉頭筋電図が 必要とされている1,2)

今回，われわれは喉頭筋電図を用い甲状披裂筋麻痺 と診断した 5 症例を経験したので，若干の文献的考察 を加え報告する。

\section{症例}

1. 症例の提示（表 1)

1 ）症例 1：77 歳，女性

胆囊癌疑いにて，全身麻酔下に胆囊摘出術が施行さ れた。術後から嗄声が出現し，嗄声の精査目的で術後 6 日目に当科紹介となった。

初診時所見：嗄声は気息性が強く, 高音発声を指示 しても胸声区発声は可能であったが，頭声区発声は不 可能であった。聴覚的印象は G(2)R (1)B (2) A (1)S (0) であった。喉頭内視鏡検查では，左右の声帯の内転外 転運動は正常であったが，右声带は弓状弛緩を呈して おり，発声時に声門間隙を認めた（図 1 上段）。喉頭 ストロボスコピーでは，粘膜波動に振幅と位相差を認
めた。われわれは右甲状披裂筋麻瘏を疑い，喉頭筋電 図を施行した。

喉頭筋電図：確定診断のため術後 12 日目に喉頭筋 電図を施行した。喉頭筋電図は同心針電極を用いて経 皮的に左右の輪状甲状筋と甲状披裂筋におのおの別々 に刺して行った。健側の輪状甲状筋と甲状披裂筋，患 側の輪状甲状筋は正常の筋放電を認めたが，患側の甲 状披裂筋の及筋放電を認めず（図 2)，右甲状披裂筋 麻痺と診断した。

経過：術後腹水の貯留と発熱からステロイド使用は 困難であり，メコバラミン（メチコバール® $\left.{ }^{\circledR}\right)$ の内服 を行った。術後 1 カ月の喉頭内視鏡で右声带の弓状弛 緩は小さくなり，喉頭ストロボスコピーで声門間隙は 小さくなっていた，自覚的に声は少し出やすくなり， 術後約 1 力月半で自覚的に声は元に戻った. 術後約 2 力 月の喉頭内視鏡で右声带の弓状弛緩は改善し, 喉頭ス トロボスコピーで粘膜波動に左右差はなく，声門閉鎖 を認めるようになり，右甲状披裂筋麻瘏の回復と判断 した（図 1 下段）。頭声区発声も可能となり，聴覚的 印象の GRBAS もすべて（0）となった.

2) 症例 2:48 歳, 女性

感冒後より嗄声が出現し，精査加療目的にて当科紹 介となった，症例 1 と同様に喉頭内視鏡と喉頭筋電図

表 15 症例の一覧

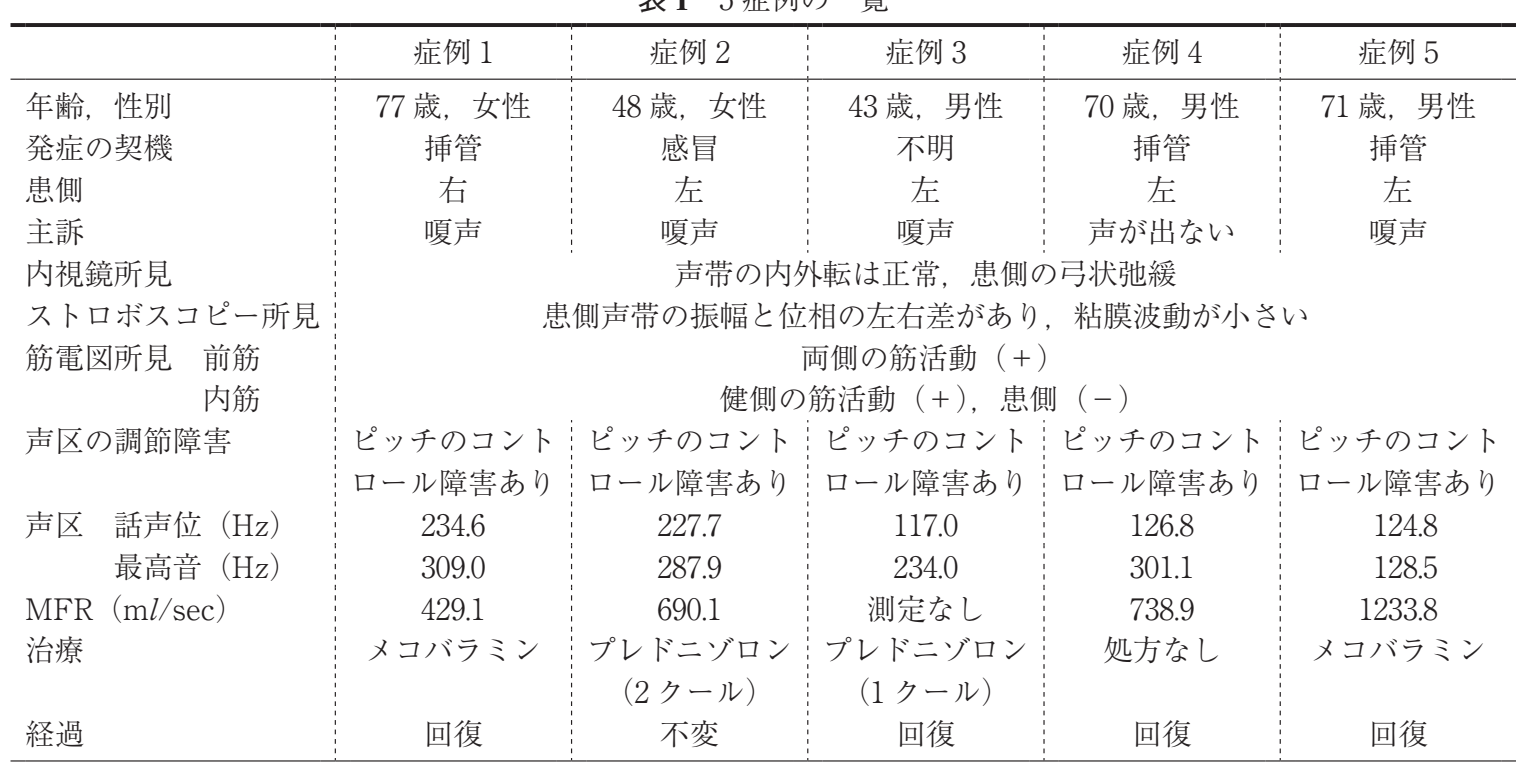



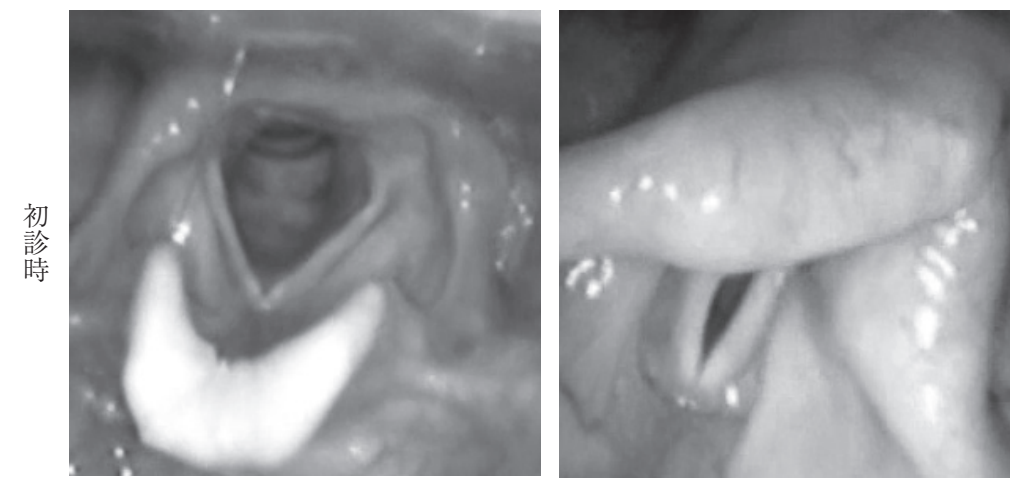

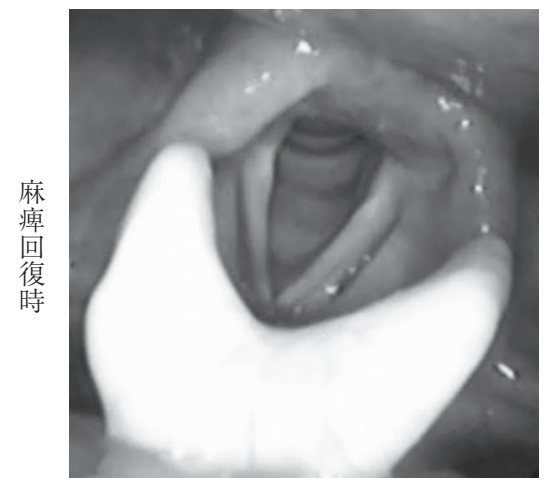

安静時

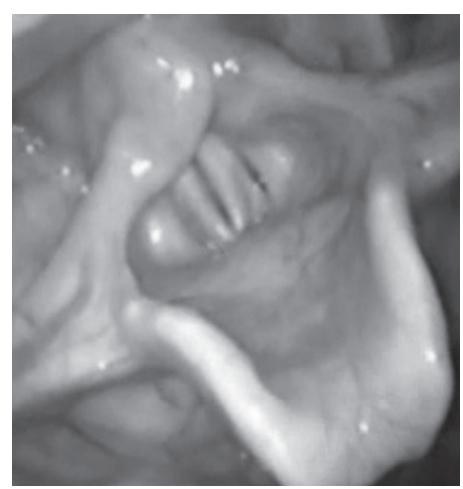

発声時

(喉頭内視鏡)

図 1 症例 1 の喉頭内視鏡および喉頭ストロボスコピー所見
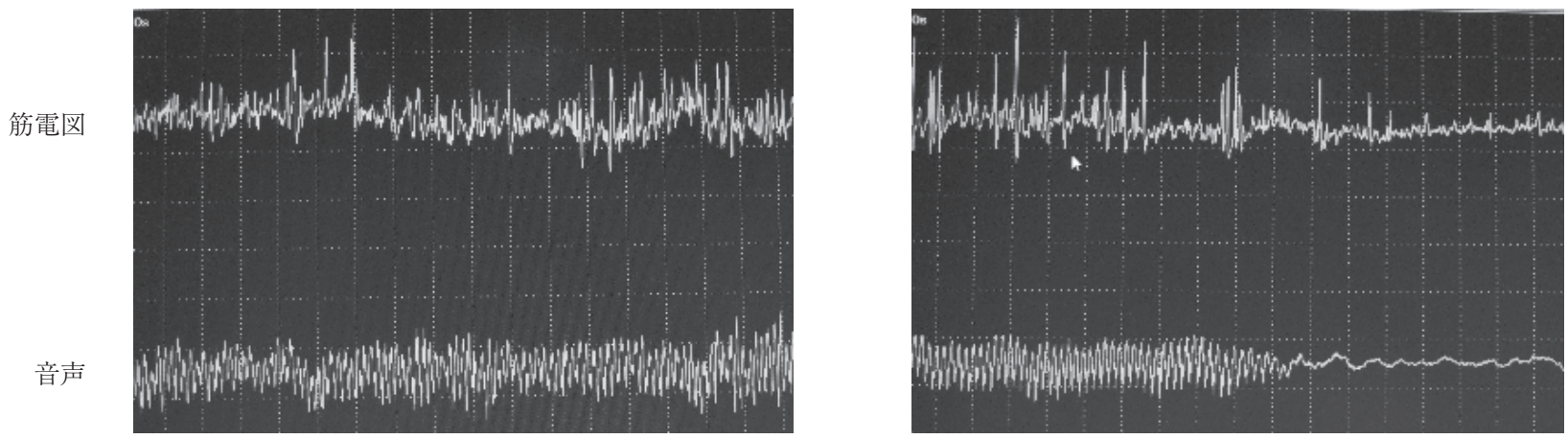

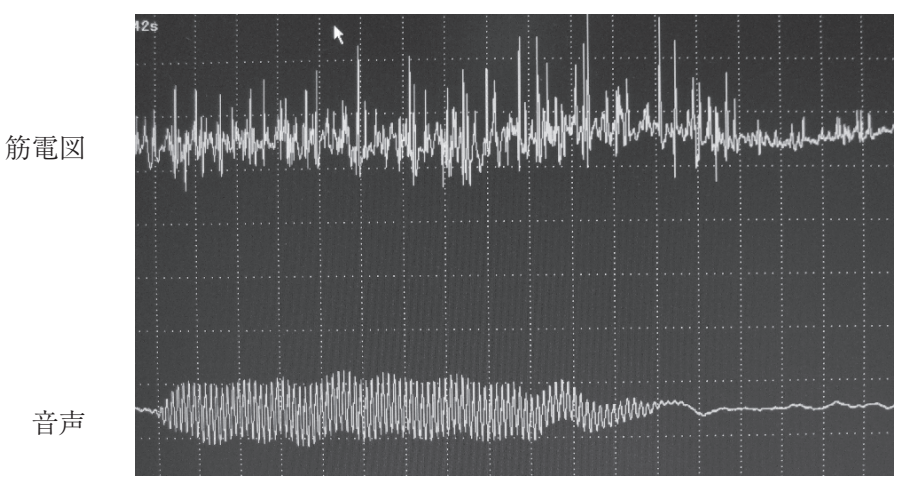

左

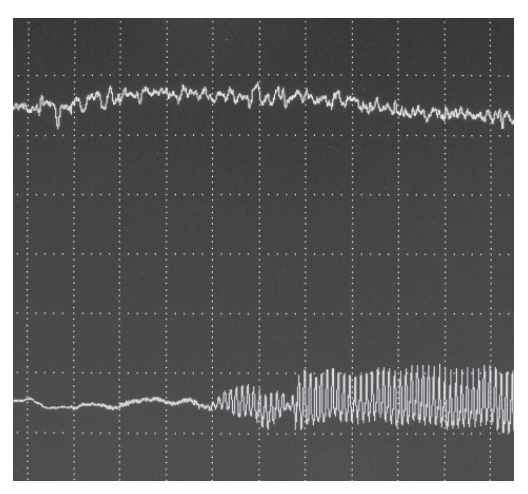

右

図 2 症例 1 の喉頭筋電図（甲状披裂筋） 
検査を行い，左甲状披裂筋麻痺と診断した，聴覚的印 象は $\mathrm{G}(2) \mathrm{R}(1) \mathrm{B}(2) \mathrm{A}(0) \mathrm{S}(0)$ であった。プレドニゾ ロン内服による漸減療法（プレドニン ${ }^{\circledR} 5 \mathrm{mg}, 1$ クー ル目 6 錠 3 日・ 4 錠 3 日・ 2 錠 3 日, 2 クール目 6 錠 3 日・ 4 錠 3 日・2 錠 3 日・1 錠 8 日）を行ったが, 左 甲状披裂筋麻瘏は回復しなかった。

3 ) 症例 3:43 歳, 男性

ゴールデンウィーク明けから急に声がかすれて出な くなり,さらに悪化したため, 発症 1 カ月して近医耳 鼻咽喉科を受診し，精査加療目的にて当科紹介となっ た。喉頭内視鏡と喉頭筋電図にて左甲状披裂筋麻痺と 診断した。聴覚的印象は G(2)R (1)B(2)A (0)S (0)で あった。プレドニゾロン内服による漸減療法（プレド ニン ${ }^{\circledR} 5 \mathrm{mg}, 6$ 錠 3 日・4 錠 3 日・ 2 錠 2 日）を 1 クー ル行った。発症 3 カ月で自覚的に声は出るようになっ てきた，喉頭内視鏡と喉頭ストロボスコピーで，粘膜 波動の左右差および声門間隙は消失し，左甲状披裂筋 麻痺の回復と判断した。

\section{4 ) 症例 4:70 歳, 男性.}

肝臓癌にて全身麻酔下に肝部分切除術が施行され, 術直後より声が出なくなった。前医耳鼻科を受診し, 喉頭内視鏡で声带運動に左右差を認め, CT で披裂軟 骨脱臼が疑われたため，全身状態が落ち着いた術後 5 週目に当科紹介となった。喉頭内視鏡で声帯の内転外 転運動は正常も, 左声帯の弓状弛緩を認め, 左甲状披 裂筋麻瘏を疑った。聴覚的印象は G(3) R (1)B (3) A (1) $\mathrm{S}(0)$ であった。 その数日後から声が出るようになっ てきたが，術後 7 週目に行った喉頭筋電図で左甲状披 裂筋に小さな筋放電を認めるのみであり，左甲状披裂 筋麻疩と診断した。肝臓癌術後で腰椎の圧迫骨折もあ り，筋電図で小さいながらも筋放電を認めたため，プ レドニゾロンは処方せず経過観察とした。術後 2 カ月
半，左甲状披裂筋麻瘏は回復した。

5 ) 症例 5:71歳, 男性.

肝臓癌にて全身麻酔下に肝部分切除術が施行され た。術直後から嗄声が続いていた。発症 10 日目に精 查目的にて当科紹介となった。初診時の喉頭内視鏡で は左声帯の弓状弛緩を認め, 聴覚的印象は G(3)R (1) B (3) A (0)S(0)であった。同日に行った喉頭筋電図で は，左甲状披裂筋のみ筋放電を認めなかったため，左 甲状披裂筋麻疩と診断した。肝臓癌術後にて,メコバ ラミン (メチコバール $\left.{ }^{\circledR}\right)$ のみで経過観察とした。発 症 1 力月半頃より声が出るようになり, 発症 3 力月の 喉頭内視鏡および喉頭ストロボスコピー検査で弓状弛 緩および声門間隙は改善していた。その 1 週間後に施 行した喉頭筋電図で，左甲状披裂筋の筋放電を確認し (図 3), 神経学的にも左甲状披裂筋麻痺の回復と判断 した。

\section{2 . 音声検査}

5 症例とも，話声位は正常範囲内であったが，高音 発声を指示しても胸声区発声は可能であったが，頭声 区発声は不可能で，ピッチ調節が困難であった。空気 力学的検査の行えた 4 例の平均呼気流率 (mean flow rate：MFR）は 429.1 1233.8 ml/sec (平均 $773.0 \mathrm{ml}$ sec）と，MFRの正常範囲を大きく超えていた。これ は患側声帯が弓状弛緩を呈し，発声時に声門閉鎖が不 完全であったためと思われた。

\section{3. 喉頭内視鏡および喉頭ストロボスコピー所見}

喉頭内視鏡では, 声帯の内転外転運動は正常であり, 発声時に弓状の声門間隙が認められた。また喉頭ス卜 ロボスコピーでは，発声中の閉鎖期における声門閉鎖 不全と発声時に健側声帯の振動が不定な振動を呈し, ときに同期したり同期が外れたりする所見が観察され た2,3)

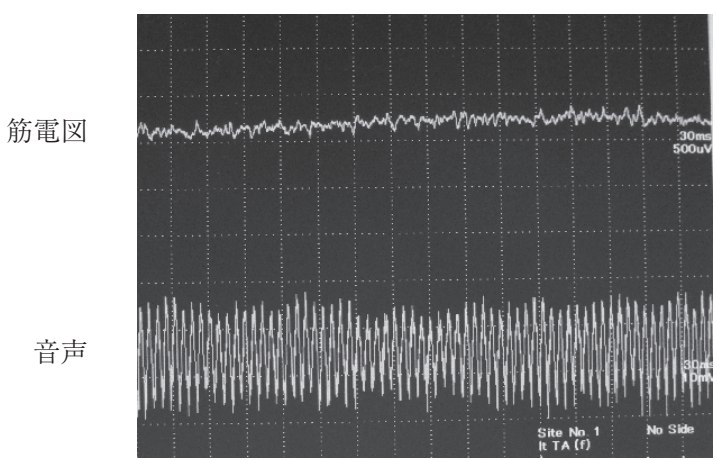

発症後

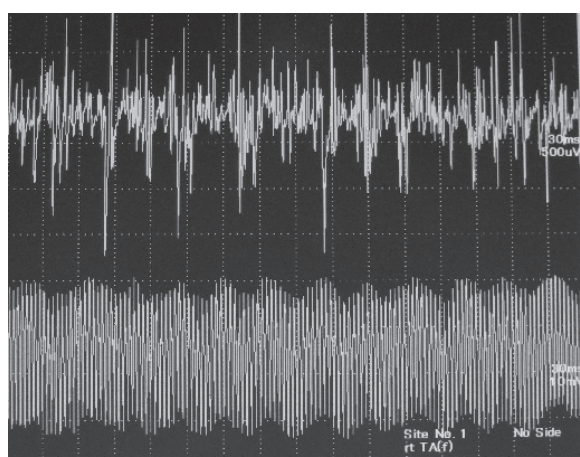

回復後

図 3 症例 5 の喉頭筋電図（左内筋） 


\section{4. 原因}

今回 5 症例のうち 3 例は全身麻酔下の術後に甲状披 裂筋麻痺を生じていた。磯貝 ${ }^{3)}$ は, 挿管性内筋麻痺は, 喉頭内腔からのカフ圧によって甲状軟骨と披裂軟骨間 を前後に走行する内筋が甲状軟骨板側に圧迫され，内 筋内に分枝した甲状披裂筋枝だけが選択的に循環障害 を起こして内筋麻瘏を発症しうることは容易に推察で きる，と述べている。今回の挿管の既往のある 3 症例 において，女性である症例 1 の挿管チューブはカフ付 きの内径 $7.5 \mathrm{~mm}$ ，手術時間は 4 時間で麻酔時間は 6 時間であった。男性である症例 4 の挿管チューブはカ フ付きの内径 $8.0 \mathrm{~mm}$, 手術時間は 7 時間 14 分, 麻酔 時間は 9 時間であった. 男性である症例 5 の挿管チュー ブはカフ付きの内径 $8.0 \mathrm{~mm}$, 手術時間は 6 時間 36 分, 麻酔時間は 8 時間 5 分であった. 3 例とも術中の体位 変換や頸部の伸展などなく，特に太い挿管チューブも 使用されていなかった。

\section{5. 麻痺の回復時期}

甲状披裂筋麻痺の回復した 4 症例の平均期間は，約 3 カ月であった.

\section{考察}

\section{1. 鑑別疾患}

声帯の内転と外転運動が正常であり，発声時に弓状 弛緩による声門間隙を認める疾患との鑑別が必要にな る。このような声門間隙をきたす疾患として, 声帯溝 症，声带萎縮，長期挿管後声門閉鎖不全，パーキンソ ン病に伴う声門閉鎖不全などがいわれている2).

1 ）声帯溝症は, 声帯遊離縁に沿って溝状の㛊凹が 認められる。

2 ）声帯萎縮は声帯を構成する筋肉や粘膜の萎縮が あり，筋電図は正常所見を示す。

3 ）長期挿管後声門閉鎖不全は，何らかの原因に よって気道確保の目的のため長期に気管内挿管を受け た患者に認め，発声時に紡錘型の声門間隙を認めるこ とがある。このような症例のなかには筋電図検査を 行っても，特に所見を認めない症例がある.

4 ）パーキンソン病では, その特異的な神経学的な 臨床症状とともに，気息性嗄声を呈するが，喉頭所見 は全身の振戦に対応する声門およびその周囲の律動的 な不随意運動に特徵がある。

今回の 5 症例には, 声帯溝症や萎縮はなく,またパー キンソン病なども認めていない. 3 症例は挿管後の麻 痺であるが，筋電図検査で患側の甲状披裂筋において 筋電図波形を認めなかったため，上記に該当しないと
考えた。

\section{2，喉頭筋電図}

喉頭筋電図は，発声と筋活動のタイミングを見るた めに，筋電図と同期して音声情報を記録できるように している。患者を仰臥位にして，同心針電極（26G） を用いて経皮的に輪状甲状筋と甲状披裂筋に各筋，左 右を別々に刺入して行った ${ }^{4-6)}$.

1 ) 輪状甲状筋

輪状軟骨の下縁で正中より $5 \mathrm{~mm}$ 外側から刺入し, 刺入針は甲状軟骨結節方向に上外方に進める。深さは $1 \mathrm{~cm}$ ほどである。刺入後，筋同定のため，持続母音 発声を行わせると，発声に同期して筋電図波形が認め られる。特に頭声区 (裏声) 発声にてその筋活動は顕 著となる。

2）甲状披裂筋

輪状軟骨上縁で正中より $5 \mathrm{~mm}$ 外側から刺入し, 刺入針は甲状軟骨間膜を貫き，上外方に進める。深さ は $2 \mathrm{~cm}$ ほどである。刺入後，筋同定のため，持続母 音発声を行わせると，発声に同期して筋電四波形が認 められる。甲状披裂筋では，発声以外に息こらえに同 期して筋電四波形を認めるが，輪状甲状筋はその筋活 動は少なく，鑑別に用いられる。嚥下動作でも筋電図 波形を認めるが，燕下動作とともに針電極が筋から抜 けてしまうことがあるので，筆者らは用いていない.

筋電図波形を認めない場合は，電極が目的筋である 麻痺側の甲状披裂筋に挿入されていない可能性があ る。刺入針が確実に挿入できているかの確認は，刺入 場所を数回変えて筋電眓波形が見られないことで確認 した。

\section{3 ) 診断}

音声と同期して，両側の輪状甲状筋と健側の甲状披 裂筋での筋放電を確認し，患側甲状披裂筋で筋活動が 消失しているのを確認して，甲状披裂筋麻痺と診断し た. 後輪状披裂筋の筋活動を確認する必要があるが, 手技的に困難であるため，喉頭内視鏡で外転運動を確 認することで省略とした。

\section{3. 音声}

甲状披裂筋の筋緊張の低下により，患側の声帯が弓 状弛緩を呈し，大きな声門間隙を呈し，それによる気 息性嗄声を認めていた。また甲状披裂筋の音声学的な 機能である声区の変換7) が円滑に遂行されないため, 症状として，会話時に地声と董声が話者の意思を反映 しないで変化する所見を認めた。これは輪状甲状筋と 甲状披裂筋の拮抗作用が障害され，ピッチコントロー ルがうまくできないため，裏声が出ない状態と考えら 
れた2).

\section{4. 患側と原因}

今回 5 症例のうち 4 症例が左側であった。過去の報 告では Berry ${ }^{8)}$ は左側, 籾山も左側, 磯貝は右側の甲 状披裂筋麻痺（この症例では，喉頭筋電図は行われて いない）を報告している．8例のうち 6 例が左側であ るが，磯貝は挿管チューブの口唇への固定位置と彎曲 方向によって決定されると推察された, と述べて㧍り， 今後症例を重礼て検討していきたい.

今回の 5 症例のうち 3 症例が抻管後の麻痺であった。 全身麻酔後に声帯麻痺を認めることは，すでに多くの 文献で報告されている。㢳発症要因としては, 頸部 の過伸展 ${ }^{9}$, 10), 挿管チューブのサイズとその固定位 置9-13), カフ圧 ${ }^{9-13)}$, 挿管時間 ${ }^{11-13)}$, 腹部手術10-12), 血 中アルブミン量 ${ }^{10)}$, 麻酔科の習熟度 ${ }^{11,13)}$ などが指摘さ れている。

図 4 のように反回神経は, 喉頭内に入ってすぐに後 輪状披裂筋へ枝を出し, 次に披裂筋へ, さらに外側輪 状披裂筋へ枝を出し, 最後に甲状披裂筋にいたり, そ れらの運動を支配する ${ }^{14)}$. 今回の 3 例とも術中の体位 変換などはなく，特に太い挿管チューブが使用されて いなかったが，声帯に挿管チューブが当たることで生 じた可能性が考えられた，実際，気管内挿管を行い手 術された症例（反回神経を損傷することが考えられな (例）で，両側声帯の内転・外転運動は良いにもかか わらず，声帯が弓状弛緩を呈し，嗄声を認めるが，1 ～3 カ月で軽快する症例があり, これらの症例のなか に甲状披裂筋麻痺が存在する可能性があると思われ る.

\section{5. 治療について}

甲状披裂筋麻疩の治療として, 新美は急性期と考元 られる時期は一般の神経麻瘏と同様に内科的な治療 (神経賦活剤, 循環改善剤, ステロイド投与) が行わ れるべきである，と述べている ${ }^{21}$ ，今回全身麻酔下の 手術後に生じた 3 症例は，ステロイド治療は行わずに 回復しており，挿管後の甲状披裂筋麻瘏症例には，又 テロイド治療を行わなくても回復する可能性が高いと 思われた。しかし感冒後と特発性と考えられた 2 例は, 急性期の麻疩として，一般的に用いられているステロ イド投与を行ったが, 感冒後の症例においては回復を 認めなかった，特発性反回神経麻痖にステロイド投与 の効果はデー夕に乏しく ${ }^{15)}$, 同様に甲状披裂筋麻痺に おいても効果は不明である。今後症例を重ねて，検討 する必要があると思われた。

症例 3 のように, 喉頭筋電図で小さな筋放電を認め

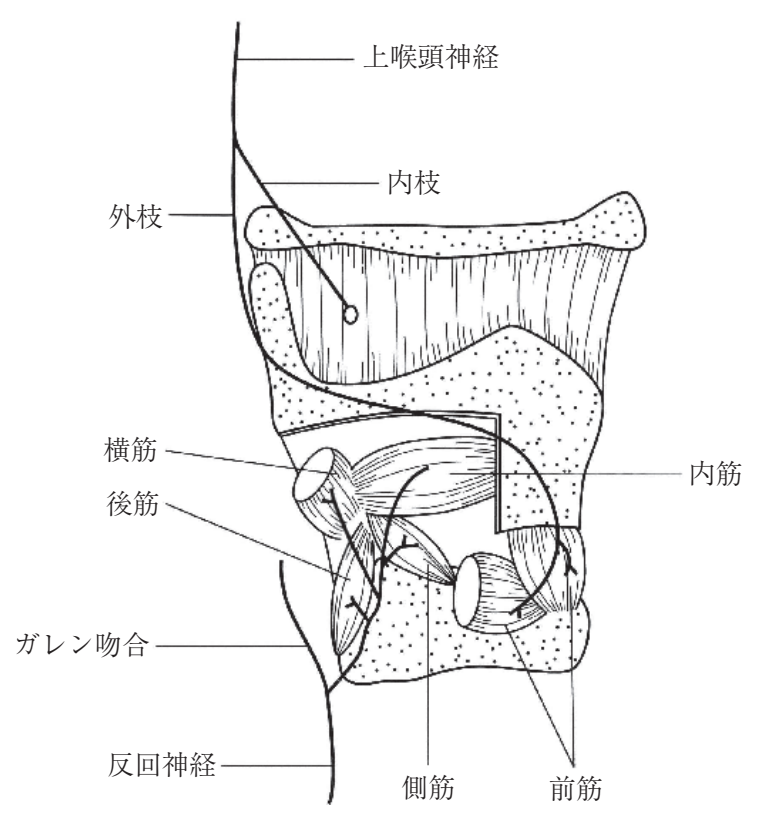

図 4 反回神経の走行

ているような場合は，神経の完全な脱神経状態ではな いため, 神経の回復の可能性が高いと思われた.

\section{結語}

1. 甲状披裂筋麻痺の喉頭所見では, 声帯の内転と 外転運動は正常で, 麻痺側声帯膜様部の弓状弛緩が顕 著であった。

2. 甲状披裂筋麻痺の診断では, 喉頭内視鏡のみで は不十分であり, 確定診断には喉頭筋電図が必要であ ると考えられた。

3，甲状披裂筋麻痺の音声所見では，声門閉鎖不全 による気息性嗄声と，甲状披裂筋と輪状披裂筋の拮抗 作用が障害された声区の調節障害が特徵的であった。

謝辞 関西医科大学耳鼻咽喉科研究助成会の援助を受けた。 利益相反自己申告：申告すべきものなし．

\section{文献}

1）籾山安弘, 新美成二：部分的喉頭麻痺一いわゆる内筋麻痺 についてー. JOHNS, 8:103-105, 1992.

2）新美成二：内喉頭筋の麻痺. JOHNS, 8：1071-1073, 1992.

3）磯貝 豊, 齋藤康一郎, 荒木幸二, 他：(本検査で診断し えた喉頭疾患症例）内筋麻痺におけるストロボスコピーの 有用性. JOHNS, $25: 613-618,2009$.

4) 廣瀬 肇：発声機能に関連するその他の検査一喉頭の筋電 図検查法. 声の検査法 臨床編, 第 2 版（日本音声言語医 学会編), 医歯薬出版, 東京, 221-234 頁, 1994.

5) 熊田政信：喉頭筋電図検査. 新編 声の検査法（日本音声 
言語医学会編), 医歯薬出版, 東京, 2008 .

6）梅野博仁, 千年俊一：喉頭 - 音声 - 言語 - その他の検査 喉頭笳電図検査. JOHNS, 29 : 1624-1627, 2013.

7）平野 実: 歌唱における声の調節. 日耳鼻, 68：91-103, 1971.

8) Berry $\mathrm{H}$ and Blair RL: Isolated vagus nerve palsy and vagal mononeuritis. Arch Otolaryngol, 106: 333-338, 1980.

9）山下隆章, 原田康夫, 上田直昭, 他 : 気管内挿管麻酔と反 回神経麻痺. 日耳鼻, 68：1452-1459, 1965.

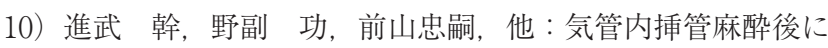
みられる反回神経麻疩について。耳鼻, 21：39-42, 1975.

11）久 育男, 豊田健司, 園田隆郎, 他：挿管性反回神経麻痺 症例の検討. 耳鼻, 36:171-174, 1990.
12）小川佳伸, 松永 喬, 宮原 裕, 他：日生病院に打ける反 回神経麻痺の臨床統計.耳鼻臨床, 87 : 505-510, 1994.

13）石田良治, 山田弘之, 藤田健一郎：術後性声帯麻疩の検討 一挿管性を中心に一。 日気食, $52: 307-312,2001$.

14）新美成二：II。解剖（神経喉頭学を含む）。新臨床耳鼻咽 喉科学 (加我君孝編), 中外医学社, 東京, 2001 .

15）廣瀬 肇:2. 喉頭麻痺. 音声障害の臨床, インテルナ出版, 東京, 1998.

別刷請求先：干573-1191 大阪府枚方市新町 2-3-1 関西医科大学枚方病院耳鼻咽喉科・頭頸部 外科

宮本 真 